\title{
Genetic Variation in the Neuropeptide $Y$ Gene Promoter Is Associated with Increased Risk of Tobacco Smoking
}

\author{
Jochen Mutschler $^{\mathrm{a}, \mathrm{b}} \quad$ Elvira Abbruzzese ${ }^{\mathrm{b}} \quad$ Christoph von der Goltz ${ }^{\mathrm{a}}$ Christina Dinter $^{\mathrm{a}}$ \\ Arian Mobascher $^{c}$ Holger Thiele ${ }^{d}$ Amalia Diaz-Lacava ${ }^{d}$ Norbert Dahmen ${ }^{c}$ Jürgen Gallinat ${ }^{f}$ \\ Tomislav Majic ${ }^{f}$ Nadine Petrovsky ${ }^{g}$ Johannes Kornhuber ${ }^{h}$ Norbert Thuerauf ${ }^{\text {h }}$ Gerhard Gründer ${ }^{i}$ \\ Jürgen Brinkmeyer ${ }^{j}$ Thomas Wienker ${ }^{\mathrm{e}}$ Michael Wagnerg ${ }^{\mathrm{g}}$ Georg Winterer $^{\mathrm{d}}$ Falk Kiefer $^{\mathrm{a}}$ \\ ${ }^{a}$ Department of Addictive Behavior and Addiction Medicine, Central Institute of Mental Health, University of Heidelberg, \\ Heidelberg, Germany; ${ }^{b}$ Department of General and Social Psychiatry, Psychiatric University Hospital Zürich, Zürich, \\ Switzerland; ' Department of Psychiatry, Johannes Gutenberg University, Mainz, ${ }^{d}$ Cologne Center for Genomics (CCG), \\ Cologne University, Cologne, ${ }^{\mathrm{e}}$ Institute of Medical Biometry, Informatics and Epidemiology, University of Bonn, Bonn, \\ fDepartment of Psychiatry, Charité University Hospital, Berlin, 9 Institute of Psychology, University of Bonn, Bonn, \\ ${ }^{h}$ Department of Psychiatry, Friedrich Alexander University Erlangen-Nürnberg, Erlangen-Nürnberg, 'Department of \\ Psychiatry and Psychotherapy, Medical Faculty, RWTH Aachen University, Aachen, and 'Department of Psychiatry, \\ Heinrich Heine University Düsseldorf, Düsseldorf, Germany
}

\section{Key Words}

Neuropeptide $\mathrm{Y}$ • Polymorphism • Nicotine - Tobacco • Smoking $\cdot$ Genetics $\cdot$ rs16147

\footnotetext{
Abstract

Background: Neuropeptide Y (NPY) is a strong candidate gene regarding the pathophysiology of tobacco dependence. It has been associated with various addictive and psychiatric disorders, and closely interacts with the brain reward system. The aim of the present study was to test for association between a functional genetic variant in the NP-Y promoter gene (SNP rs16147) and tobacco smoking. Methods: In a population-based case-control multicenter study designed for tobacco addiction research, a total of 550 Caucasian current smokers, and 544 never-smokers were genotyped for SNP rs16147 and behaviorally characterized with the State-Trait Anxiety Inventory (STAI). Results: Subjects with TT genotype of the SNP rs16147 were significantly more
}

frequently smokers than never-smokers $(p=0.046)$. In addition, TT genotype exhibited increased state anxiety scores compared to carriers of the $C$ allele $(p=0.037)$. Conclusions: Our results provide evidence for an involvement of the functionally relevant SNP rs16147 in the pathophysiology of tobacco dependence. Further studies are needed to confirm our findings.

Copyright $\odot 2012$ S. Karger AG, Basel

\section{Introduction}

Tobacco smoking is a major health problem with extensive consequences for persons concerned, and the society in general $[1,2]$. Biological, political and psycho-

\section{J. Mutschler and E. Abbruzzese contributed equally to this work.}

\section{KARGER}

Fax +4161306 1234

E-Mail karger@karger.ch

www.karger.com
(C) 2012 S. Karger AG, Basel

1022-6877/12/0185-0246\$38.00/0

Accessible online at:

www.karger.com/ear
Jochen Mutschler, MD

Department of General and Social Psychiatry

Psychiatric University Hospital Zürich

Militärstrasse 8, CH-8021 Zürich (Switzerland)

E-Mail jochen.mutschler@puk.zh.ch 
logical factors are involved in smoking behavior and tobacco dependence $[3,4]$. Twin studies have consistently estimated heritability of around 50\% for tobacco dependence $[5,6]$. Thus, genetic factors have a substantial contribution to the tobacco dependence etiology. Several different genes are associated with tobacco smoking; recently, genome-wide association studies investigated several promising genetic determinants of tobacco dependence and found strongest genetic contribution to nicotine dependence from variation in the nicotinic receptor subunits and in nicotine metabolism [7-9]. However, variation within these genes accounts for only a small proportion of the risk for developing tobacco dependence, which implies that many genes seem to be involved in this complex behavior and disease [10]. Nicotine and other substances from tobacco affect brain functions through modifying different neurotransmitter systems, and nicotine is the major addictive substance in tobacco [11]. The rewarding effects of nicotine (e.g. relief of anxiety and arousal), withdrawal symptoms (e.g. craving, irritability, dysphoric or depressed mood, anxiety, restlessness, increased appetite or weight gain and insomnia), and environmental factors (e.g. stress) are the main factors which contribute to the consolidation of the tobacco dependence [11]. Nicotine mainly binds to nicotinic acetylcholine receptors containing the $\alpha_{4}$ and $\beta_{2}$ subunits, often in combination with the $\alpha_{6}$ subunit, which are located with the highest concentrations in the mesolimbic dopaminergic reward system in the brain $[12,13]$. Nicotine is the major addictive component of tobacco and a potent agonist of neuronal nicotinic receptors (AChRs) thereby stimulating dopamine (and norepinephrine) release [14]. Hence, the dopaminergic system is considered a major pathway for tobacco use and development of tobacco dependence [15].

Neuropeptide Y (NPY), a 36-amino-acid peptide, is expressed at high levels within the nervous system [16, 17]. The NPY gene (NP-Y) is a potential candidate gene involved in nicotine dependence because NP-Y has been shown to increase extracellular dopamine levels dosedependently in the shell region of the nucleus accumbens in rats [18]. This indicates that NP-Y could play an important role in drug reinforcement by modulating dopamine levels in the brain reward system. On the other hand, the anxiolytic neuropetide NP-Y is also known as endogenous regulator of appetite and anxiety [19-21], which is both affected through tobacco smoking, and nicotine withdrawal $[11,22,23]$. Hence, NP-Y gene variations have been associated with negative effects, and numerous psychiatric diseases in a number of studies
$[20,24,25]$. Furthermore, several studies suggested a possible involvement of the NP-Y system in the neurobiological effects of different abused substances including alcohol [26], methamphetamine [27], and smoking behavior [28].

In summary, the NP-Y system has been shown to modulate drug intake behavior, anxiety, and positive rewarding properties. Taking these findings together, the NP-Y gene may be an interesting candidate gene to gain new insights into the pathophysiology of tobacco dependence. In particular, the (promotor) single nucleotide polymorphism (SNP) rs16147 has been reported to influence NP-Y gene expression on the level of mRNA and protein and accounts for a relevant part of differential expression of NPY in vitro [24, 25, 29]. We therefore analyzed whether this functional genetic variant in the NP-Y promoter gene is associated with cigarette smoking in an ethnically homogenous sample of healthy Caucasian subjects from Germany.

\section{Methods}

\section{Data Collection}

For case-control association analysis, 550 current smokers (Fagerström test 5-10 points) and 544 never-smokers (max. 20 cigarettes/lifetime), of whom 464 subjects were male and 630 were female (entire sample $n=1,094$ ), all were genotyped. Data were collected in seven recruitment centers throughout Germany (Departments of Psychiatry at the University of Aachen, Berlin, Bonn, Düsseldorf, Erlangen, Mainz, Mannheim) between the years 2007 and 2009. Inclusion criteria for subjects were: German origin and mother-tongue level German and grandparents of subjects were required to be born in Germany or in a country adjacent to Germany. Subjects with non-German ethnicity were not included. Further details of recruitment, testing procedures, inclusion/exclusion criteria, and characterization of this multicenter study on nicotine dependence and smoking-related behavior have been described previously $[23,30]$.

Inclusion/exclusion criteria were assessed through a medical examination, a standardized psychiatric interview (SCID-1), questionnaires, drug screen, alcohol testing and CO measurement. The present study was approved by the ethics committees of all participating centers; subjects were included in the study after they had given written informed consent.

\section{Psychometric Measures}

The absence of psychiatric axis-I comorbidity was verified with the Structured Clinical Interview [31] which is based on DSM-IV criteria (American Psychiatric Association, 2000). The Fagerström Questionnaire for Nicotine Dependence [32] was used as a measure for the level of nicotine dependence [33] and Heaviness of Smoking Index (HSI-G) [34]. Nicotine craving was measured via self-report with the Questionnaire of Smoking Urges (QSU) [35] (QSU German version [36]). Anxiety was as- 
Table 1. Demographic information

\begin{tabular}{llll}
\hline Parameters & $\begin{array}{l}\text { Entire sample } \\
(\mathrm{n}=1,094) \\
\text { mean }(\mathrm{SD})\end{array}$ & $\begin{array}{l}\text { Smokers } \\
(\mathrm{n}=550) \\
\text { mean }(\mathrm{SD})\end{array}$ & $\begin{array}{l}\text { Never-smokers } \\
(\mathrm{n}=544) \\
\text { mean }(\mathrm{SD})\end{array}$ \\
\hline Age, years & $34.66(12.81)$ & $36.54(12.88)$ & $32.76(12.47)$ \\
Females, $\%$ & 57.6 & 53.8 & 61.4 \\
Years of school education & $11.79(1.59)$ & $10.38(1.70)$ & $12.19(1.34)$ \\
Exhaled CO, ppm & $7.7(10.21)$ & $13.52(11.61)$ & $1.72(1.53)$ \\
Plasma cotinine, ng/ml & $51.76(133.72)$ & $99.60(155.23)$ & $3.48(83.63)$ \\
FTND & - & $2.94(2.70)$ & - \\
Cigarettes per day & - & $13.67(10.39)$ & - \\
Age of onset, years & - & $16.11(3.23)$ & - \\
Cigarettes per lifetime & - & $112,980.77(108,741.15)$ & $3.16(2.69)$ \\
AUDIT & $4.03(3.43)$ & $4.89(3.84)$ & $23.86(4.18)$ \\
BMI & $24.26(4.68)$ & $24.66(5.09)$ & $33.43(7.38)$ \\
STAI-X1 state & $34.23(8.05)$ & $35.02(8.61)$ & $34.85(8.69)$ \\
STAI-X2 trait & $35.38(9.18)$ & $35.90(9.61)$ &
\end{tabular}

SD = Standard deviation; AUDIT = alcohol use disorders identification text (Babor et al., 1992 [48]); BMI = body mass index; FTND = Fagerström Test for Nicotine Dependence (level of nicotine dependence, Heatherton et al., 1991 [32]; German version: Bleich et al., 2002 [49]); STAI = State-Trait Anxiety Inventory (Spielberger, 1970 [37]).

sessed with the trait version of the State-Trait Anxiety Inventory (STAI [37]; STAI German version [38]). Depressive symptoms were measured with the Beck Depression Inventory (BDI [39]; BDI German version [40]). Subjective experience of stress was measured by the Perceived Stress Scale (PSS [41]). To control for alcohol use the Alcohol Use Disorders Identification Test (AUDIT [42]; AUDIT German version [43]) was used.

\section{DNA Preparation and Genotyping}

Genotyping was done at the Cologne Center for Genomics (CCG), University of Cologne. DNA from fresh frozen EDTA blood was prepared with Qiagen FlexiGene DNA Kit according to the manufactory protocol and normalized based on RNase P copy number measurement using the TaqMan RNase P assay from Applied Biosystems ${ }^{\circledR}$ (Foster City, Calif., USA). The SNP rs16147, a functional NP-Y promoter variant, was chosen to cover the functional expression of brain NP-Y. Genotyping was performed with SNPstream SNP genotyping assays. Genotyping call rates were 99\%. All laboratory procedures were carried out blind to casecontrol status.

\section{Data Analysis}

The baseline demographics and clinical characteristics were compared between smokers and non-smokers. Descriptive statistics were calculated with $t$ tests for independent samples and are given with mean and standard deviation. The Levene test was used to assess the homogeneity of variance. Associations between the genotype and smoking behavior were evaluated using the $\chi^{2}$ test, while the interaction effect of genotype and smoking behavior on the interval-scaled scores of the anxiety questionnaire (STAXI X1) was assessed with analysis of variance (univariate
ANOVA). Where necessary, separate post-hoc t tests were performed for the three genotypes. The $\mathrm{p}$ value for the post-hoct tests was adjusted to 0.017 in order to control for the type I error. All other test statistics indicating a p value of 0.05 or less were considered significant. Tests for deviation from Hardy-Weinberg equilibrium were performed using an exact test. Data analysis was performed using SPSS Statistics, version 19.

\section{Results}

A total of 1,094 subjects (550 current smokers and 544 never-smokers) were genotyped for SNP rs16147. Mean age was $34.7 \pm 12.8$ years. SNP rs16147 did not deviate from Hardy-Weinberg equilibrium $(\mathrm{TT}=257$, $23.6 \%, \mathrm{CT}=557,51.1 \%$, and CC $=277,25.4 \%$; for nonsmokers $\mathrm{p}=0.086$, for smokers $\mathrm{p}=0.444)$. Sociodemographic and clinical characteristics of the study population are presented in table 1.

We found a significant difference in the number of allele carriers between the group of smokers and nonsmokers: $\chi^{2}$ analysis revealed a significantly higher probability for TT genotype of being a smoker compared to being a non-smoker $\left(\chi^{2}=4.74 ; \mathrm{p}=0.029\right)$. However, comparisons of CC and CT alleles between the two groups did not show significant differences (CC: d.f. $=1, \mathrm{p}=1.0$; CT: d.f. $=1, p=0.271$ ) (fig. 1 ; table 2). The ratio between smok- 


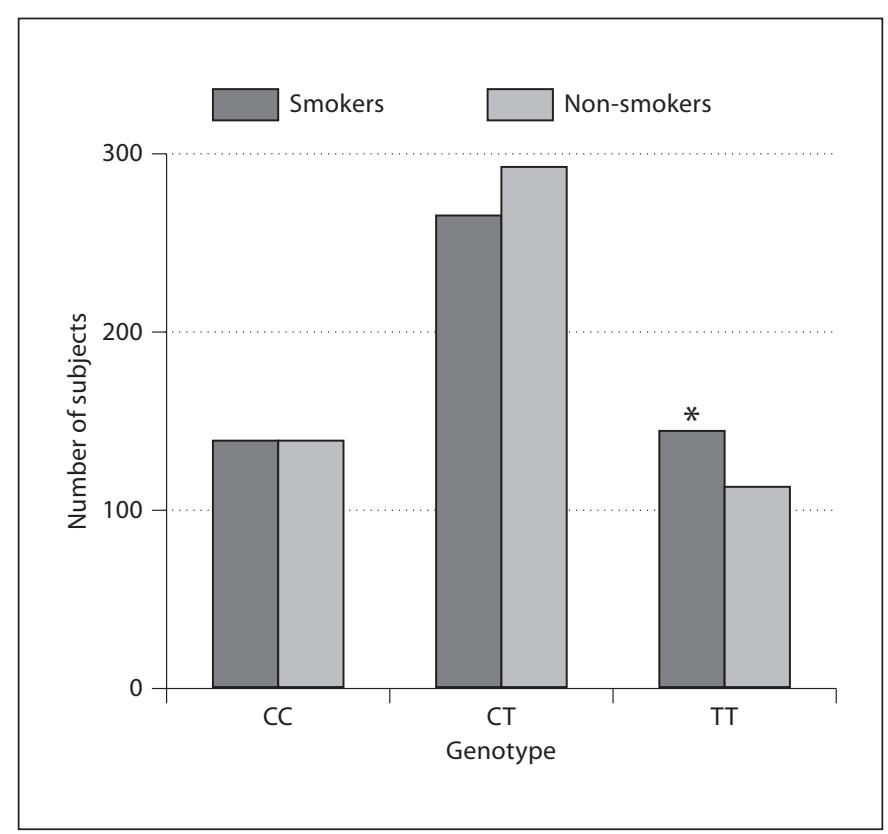

Fig. 1. Number of subjects analyzed for the SNP rs16147 (smokers vs. non-smokers): $\mathrm{TT}=257,23.6 \%, \mathrm{CT}=557,51.1 \%$, and $\mathrm{CC}=277$, $25.4 \%$. ${ }^{*} \mathrm{TT}$ allele carriers had a significantly higher probability of being a smoker compared to being a non-smoker $(\mathrm{p}<0.05)$. CC and CT alleles between the two groups did not show significant differences $(\mathrm{p}>0.05)$.

Table 2. Genotype and smoking status

\begin{tabular}{llll}
\hline SNP rs16147 & $\mathrm{n}$ & $\chi^{2}$ & $\mathrm{p}$ \\
\hline CC smokers & 139 & 0.000 & 1.000 \\
CC non-smokers & 139 & & \\
\hline CT smokers & 266 & 1.211 & 0.271 \\
CT non-smokers & 292 & & \\
\hline TT smokers & 145 & 3.969 & 0.046 \\
TT non-smokers & 113 & & \\
\hline
\end{tabular}

ers and non-smokers in CC/CT allele carriers is 0.94, while the ratio between smokers and non-smokers in TT allele carriers is 1.28 . The OR and CI for CC/CT compared to TT allele carriers is $\mathrm{OR}=0.732, \mathrm{CI}=0.553-$ 0.970 .

In an omnibus interaction analysis, smokers compared to non-smokers showed a significantly higher state anxiety score (STAI X1) $(\mathrm{F}=11.790 ;$ d.f. $=1 ; \mathrm{p}=0.001)$

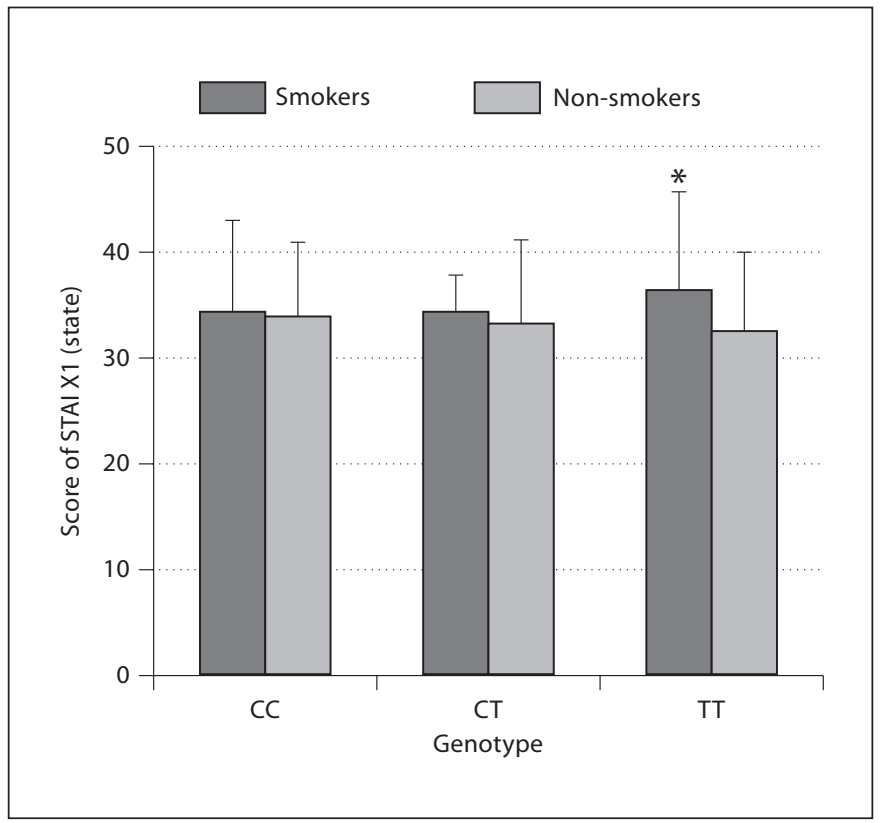

Fig. 2. Scores of the STAI1 questionnaire (smokers vs. non-smokers). * There are significantly higher scores of the STAI1 questionnaire in TT allele carriers who smoked compared to the TT allele carriers who never smoked $(\mathrm{p}<0.05)$. Comparisons of CC and $\mathrm{CT}$ alleles between the two groups did not show significant differences $(\mathrm{p}>0.05)$.

but not trait anxiety score (STAI X2) $(\mathrm{F}=2.833$; d.f. $=1$; $\mathrm{p}=0.093)$. This effect was specifically accentuated within the TT allele carriers: the interaction effect (smoking status $\times$ genotype) indicates significantly higher scores of the STAI X1 questionnaire in TT allele carriers who smoked compared to the TT allele carriers who never smoked $(\mathrm{F}=3.317 ; \mathrm{d} . \mathrm{f} .=2 ; \mathrm{p}=0.037)$. This effect was posthoc additionally and separately tested for the three genotypes and resulted in a highly significant difference between smokers and non-smokers in the TT allele carriers $(\mathrm{T}=3.590 ; \mathrm{p}<0.000)$ (fig. 2). However, this interaction effect (smoking status $\times$ genotype) was not found concerning trait anxiety (STAI X2) $(\mathrm{F}=1.213$; d.f. $=1 ; \mathrm{p}=$ 0.298).

We did not observe significant differences between the different alleles of the SNP rs16147 concerning the age of onset of tobacco dependence, FTND scores, pack-years, amount cigarettes smoked per day, and tobacco craving (QSU) (data not shown). 


\section{Discussion}

The main result of our study is the finding that the risk variant of the SNP rs16147 (TT allele), located in the NP-Y gene promoter, is associated with increased probability of tobacco smoking behavior. TT allele (rs16147) carriers have a significantly higher probability of being a smoker, compared to CC and CT allele carriers. However, we did not find differences concerning the age of onset of tobacco dependence, amount of cigarettes smoked per day, and tobacco craving (QSU) between the different genotypes. Numerous studies on the effects of rs16147 on NP-Y gene expression have been reported in the literature, reporting rather mixed and conflict results [24, 44-46]. However, the $\mathrm{C}$ allele was identified as the high NP-Y expressing allele in most reports. Our results are consistent with reports suggesting that TT allele carriers (rs16147) show reduced gene expression of the anxiolytic protein NPY. We found significantly higher scores of the STAI1 questionnaire in TT allele carriers who smoked compared to the TT allele carriers who never smoked. Recently published data support our results, reporting the T allele of rs16147 is associated with anxiety and depressive symptoms in young adults $[24,29]$. This might be a consequence of the reduced gene expression of the anxiolytic protein NPY in $\mathrm{T}(\mathrm{T})$ allele carriers (rs16147). It is well known that patients with psychiatric disorders (e.g. anxiety disorders) have a higher risk to develop tobacco dependence. In addition to shared genetic risk factors of psychiatric disorders and tobacco dependence, the anxiety and stress attenuation effects of nicotine are known to play an important role in the development of tobacco addiction. Especially in pathophysiological mechanisms of anxiety/depression and substance abuse, NP-Y has been implicated repeatedly [20, 26-28, 47]. Since the biological effects of NP-Y are substantially controlled by the NP-Y gene, the increased state anxiety and associated risk of tobacco smok- ing might be a compensation of the impaired NP-Y expression of TT allele carriers (rs16147). This hypothesis is based on the observation that NPY has an important function in counter-regulating states of anxiety [20].

Taken together, our results suggest an involvement of the NPY system in tobacco smoking. We found individuals carrying the risk genotype TT of rs16147, associated with reduced NP-Y levels in former studies, have significantly higher state anxiety and have a higher individual vulnerability for tobacco smoking. However, the TT allele of rs16147 was not associated with higher tobacco craving, earlier age of onset of tobacco dependence, and higher amount of cigarettes smoked per day, implying additional risk factors which contribute to the complex disease of tobacco dependence. Our study has some limitations: Whether rs16147 directly or indirectly influences NP-Y expression, or whether it acts through other pathways has not been investigated so far and should be targeted in further studies. However, in our large case-control study, we found that a mutation in the NP-Y gene promoter may constitute a genetic risk factor for tobacco dependence. Further studies are needed to replicate our findings and to further elucidate other genetic risk variants of tobacco dependence.

\section{Acknowledgments}

We would like to thank Carsten Wied for his assistance in data collection. Funding for this study was provided within the framework of the German Priority Program SPP1226 'Nicotine - Molecular and Physiological Mechanisms in CNS' by grants from the German Research Foundation (DFG KI 782/5-1 and Wi1316/9-1).

\section{Disclosure Statement}

The authors have no conflicts of interest to disclose.

\section{References}

1 Ezzati M, Henley SJ, Thun MJ, Lopez AD: Role of smoking in global and regional cardiovascular mortality. Circulation 2005;112: 489-497.

- Ezzati M, Lopez AD: Estimates of global mortality attributable to smoking in 2000 . Lancet 2003;362:847-852.

3 Batra V, Patkar AA, Berrettini WH, Weinstein SP, Leone FT: The genetic determinants of smoking. Chest 2003;123:1730-1739.
Ringlever L, Otten R, de Leeuw RN, Engels RC: Effects of parents' education and occupation on adolescent smoking and the mediating role of smoking-specific parenting and parent smoking. Eur Addict Res 2011;17:5563.

5 Li MD, Cheng R, Ma JZ, Swan GE: A metaanalysis of estimated genetic and environmental effects on smoking behavior in male and female adult twins. Addiction 2003;98: 23-31.
6 Vink JM, Willemsen G, Boomsma DI: Heritability of smoking initiation and nicotine dependence. Behav Genet 2005;35:397-406.

7 Tobacco and Genetics Consortium: Genome-wide meta-analyses identify multiple loci associated with smoking behavior. Nat Genet 2010;42:441-447. 
$>8$ Liu JZ, Tozzi F, Waterworth DM, Pillai SG, Muglia P, Middleton L, Berrettini W, Knouff CW, Yuan X, Waeber G, Vollenweider P, Preisig M, Wareham NJ, Zhao JH, Loos RJ, Barroso I, Khaw KT, Grundy S, Barter P, Mahley R, Kesaniemi A, McPherson R, Vincent JB, Strauss J, Kennedy JL, Farmer A, McGuffin P, Day R, Matthews K, Bakke P, Gulsvik A, Lucae S, Ising M, Brueckl T, Horstmann S, Wichmann HE, Rawal R, Dahmen N, Lamina C, Polasek O, Zgaga L, Huffman J, Campbell S, Kooner J, Chambers JC, Burnett MS, Devaney JM, Pichard AD, Kent KM, Satler L, Lindsay JM, Waksman R, Epstein S, Wilson JF, Wild SH, Campbell H, Vitart V, Reilly MP, Li M, Qu L, Wilensky R, Matthai W, Hakonarson HH, Rader DJ, Franke A, Wittig M, Schafer A, Uda M, Terracciano A, Xiao X, Busonero $\mathrm{F}$, Scheet $\mathrm{P}$, Schlessinger D, St Clair D, Rujescu D, Abecasis GR, Grabe HJ, Teumer A, Volzke H, Petersmann A, John U, Rudan I, Hayward C, Wright AF, Kolcic I, Wright BJ, Thompson JR, Balmforth AJ, Hall AS, Samani NJ, Anderson CA, Ahmad T, Mathew CG, Parkes M, Satsangi J, Caulfield M, Munroe PB, Farrall $\mathrm{M}$, Dominiczak $\mathrm{A}$, Worthington J, Thomson W, Eyre S, Barton A, Mooser V, Francks C, Marchini J: Meta-analysis and imputation refines the association of $15 q 25$ with smoking quantity. Nat Genet 2010;42: 436-440.

$>9$ Thorgeirsson TE, Gudbjartsson DF, Surakka I, Vink JM, Amin N, Geller F, Sulem P, Rafnar T, Esko T, Walter S, Gieger C, Rawal R, Mangino M, Prokopenko I, Magi R, Keskitalo K, Gudjonsdottir IH, Gretarsdottir S, Stefansson H, Thompson JR, Aulchenko YS, Nelis M, Aben KK, den Heijer M, Dirksen A, Ashraf H, Soranzo N, Valdes AM, Steves C, Uitterlinden AG, Hofman A, Tonjes A, Kovacs $P$, Hottenga JJ, Willemsen G, Vogelzangs N, Doring A, Dahmen N, Nitz B, Pergadia ML, Saez B, De Diego V, Lezcano V, Garcia-Prats MD, Ripatti S, Perola M, Kettunen J, Hartikainen AL, Pouta A, Laitinen J, Isohanni M, Huei-Yi S, Allen M, Krestyaninova M, Hall AS, Jones GT, van Rij AM, Mueller T, Dieplinger B, Haltmayer M, Jonsson S, Matthiasson SE, Oskarsson H, Tyrfingsson T, Kiemeney LA, Mayordomo JI, Lindholt JS, Pedersen JH, Franklin WA, Wolf H, Montgomery GW, Heath AC, Martin NG, Madden PA, Giegling I, Rujescu D, Jarvelin MR, Salomaa V, Stumvoll M, Spector TD, Wichmann HE, Metspalu A, Samani NJ, Penninx BW, Oostra BA, Boomsma DI, Tiemeier H, van Duijn CM, Kaprio J, Gulcher JR, McCarthy MI, Peltonen L, Thorsteinsdottir U, Stefansson K: Sequence variants at CHRNB3-CHRNA6 and CYP2A6 affect smoking behavior. Nat Genet 2010;42:448453.

$>10$ Bierut LJ: Genetic vulnerability and susceptibility to substance dependence. Neuron 2011;69:618-627.
Benowitz NL: Nicotine addiction. N Engl J Med 2010;362:2295-2303.

12 Dajas-Bailador F, Wonnacott S: Nicotinic acetylcholine receptors and the regulation of neuronal signalling. Trends Pharmacol Sci 2004;25:317-324.

13 De Biasi M, Dani JA: Reward, addiction, withdrawal to nicotine. Annu Rev Neurosci 2011;34:105-130.

14 Le Foll B, Gallo A, Le Strat Y, Lu L, Gorwood P: Genetics of dopamine receptors and drug addiction: a comprehensive review. Behav Pharmacol 2009;20:1-17.

15 Dani JA, De Biasi M: Cellular mechanisms of nicotine addiction. Pharmacol Biochem Behav 2001;70:439-446.

16 Benarroch EE: Neuropeptide Y: its multiple effects in the CNS and potential clinical significance. Neurology 2009;72:1016-1020.

17 Silva AP, Xapelli S, Grouzmann E, Cavadas $\mathrm{C}$ : The putative neuroprotective role of neuropeptide $\mathrm{Y}$ in the central nervous system. Curr Drug Targets CNS Neurol Disord 2005; 4:331-347.

18 Sorensen G, Wegener G, Hasselstrom J, Hansen TV, Wortwein G, Fink-Jensen A, Woldbye DP: Neuropeptide Y infusion into the shell region of the rat nucleus accumbens increases extracellular levels of dopamine. Neuroreport 2009;20:1023-1026.

19 Chee MJ, Colmers WF: Y eat? Nutrition 2008;24:869-877.

20 Heilig M: The NPY system in stress, anxiety and depression. Neuropeptides 2004;38: 213-224.

21 Karl T, Herzog H: Behavioral profiling of NPY in aggression and neuropsychiatric diseases. Peptides 2007;28:326-333.

22 Hughes JR: Clinical significance of tobacco withdrawal. Nicotine Tob Res 2006;8:153156.

23 Koopmann A, Dinter C, Grosshans M, von der Goltz C, Hentschel R, Dahmen N, Gallinat J, Wagner M, Grunder G, Thurauf N, Wienker T, Brinkmeyer J, Mobascher A, Spreckelmeyer KN, Clepce M, de Millas W, Wiedemann K, Winterer G, Kiefer F: Psychological and hormonal features of smokers at risk to gain weight after smoking cessation - results of a multicenter study. Horm Behav 2011;60:58-64.

24 Sommer WH, Lidstrom J, Sun H, Passer D, Eskay R, Parker SC, Witt SH, Zimmermann US, Nieratschker V, Rietschel M, Margulies EH, Palkovits M, Laucht M, Heilig M: Human NPY promoter variation rs16147:T $>C$ as a moderator of prefrontal NPY gene expression and negative affect. Hum Mutat 2010;31:E1594-1608.

25 Zhou Z, Zhu G, Hariri AR, Enoch MA, Scott D, Sinha R, Virkkunen M, Mash DC, Lipsky RH, Hu XZ, Hodgkinson CA, Xu K, Buzas B, Yuan Q, Shen PH, Ferrell RE, Manuck SB, Brown SM, Hauger RL, Stohler CS, Zubieta JK, Goldman D: Genetic variation in human NPY expression affects stress response and emotion. Nature 2008;452:997-1001.
6 Zill P, Preuss UW, Koller G, Bondy B, Soyka $\mathrm{M}$ : Analysis of single nucleotide polymorphisms and haplotypes in the neuropeptide Y gene: no evidence for association with alcoholism in a German population sample. Alcohol Clin Exp Res 2008;32:430-434.

27 Okahisa Y, Ujike H, Kotaka T, Morita Y, Kodama M, Inada T, Yamada M, Iwata N, Iyo M, Sora I, Ozaki N, Kuroda S: Association between neuropeptide $Y$ gene and its receptor Y1 gene and methamphetamine dependence. Psychiatry Clin Neurosci 2009;63: 417-422.

28 Sato N, Kageyama S, Chen R, Suzuki M, Mori H, Tanioka F, Yamada H, Kamo T, Tao H, Shinmura K, Nozawa A, Sugimura H: Association between neuropeptide Y receptor 2 polymorphism and the smoking behavior of elderly Japanese. J Hum Genet 2010;55:755760.

29 Witt SH, Buchmann AF, Blomeyer D, Nieratschker V, Treutlein J, Esser G, Schmidt $\mathrm{MH}$, Bidlingmaier M, Wiedemann K, Rietschel M, Laucht M, Wust S, Zimmermann US: An interaction between a neuropeptide $\mathrm{Y}$ gene polymorphism and early adversity modulates endocrine stress responses. Psychoneuroendocrinology 2011;36:1010-1020.

30 Lindenberg A, Brinkmeyer J, Dahmen N, Gallinat J, de Millas W, Mobascher A, Wagner M, Schulze-Rauschenbach S, Grunder G, Spreckelmeyer KN, Clepce M, Thurauf N, von der Goltz C, Kiefer F, Steffens M, Holler D, Diaz-Lacava A, Wienker T, Winterer G: The German multi-centre study on smoking-related behavior-description of a population-based case-control study. Addict Biol 2011;16:638-658.

31 Wittchen HU, Zaudig M, Fydrich T: SKID. Strukturiertes Klinisches Interview für DSM-IV. Achse I und II. Handanweisung, 1997.

32 Heatherton TF, Kozlowski LT, Frecker RC, Fagerström KO: The Fagerström Test for Nicotine Dependence: a revision of the Fagerström Tolerance Questionnaire. Br J Addict 1991;86:1119-1127.

33 Schumann A, Rumpf HJ, Meyer C, Hapke U, John U: Deutsche Version des FagerströmTest for Nicotine Dependence (FTND-G) und des Heaviness of Smoking Index (HSIG), 2003.

34 Heaviness of Smoking Index (HSI-G). Mannheim, Methoden und Analysen. Zentrum für Umfragen.

35 Tiffany ST, Drobes DJ: The development and initial validation of a questionnaire on smoking urges. Br J Addict 1991;86:14671476.

36 Mueller V, Mucha, RF, Ackermann K: The assessment of craving in smokers with a German version of the Questionnaire on Smoking Urges (QSUG). Z Klin Psychol Psychother 2001;30:164-171. 
37 Spielberger CD: Manual for the State-Trait Anxiety Inventory (Self-Evaluation Questionnaire). Palo Alto, Consulting Psychologists Press, 1970.

38 Laux L, Glanzmann P, Schaffner P, Spielberger CD: State-Trait-Angstinventar, 1981.

- 39 Beck AT, Ward CH, Mendelson M, Mock J, Erbaugh J: An inventory for measuring depression. Arch Gen Psychiatry 1961;4:561571.

40 Hautzinger M, Bailer M, Worall H, Keller F: Beck-Depressions-Inventar (BDI). Testhandbuch. Bern, Huber, 1995.

-41 Cohen S, Kamarck T, Mermelstein R: A global measure of perceived stress. J Health Soc Behav 1983;24:385-396.
42 Saunders JB, Aasland OG, Babor TF, de la Fuente JR, Grant M: Development of the Alcohol Use Disorders Identification Test (AUDIT): WHO Collaborative Project on Early Detection of Persons with Harmful Alcohol Consumption. II. Addiction 1993; 88:791-804.

43 Rumpf H-J, Meyer C, Hapke U, John U: The Alcohol Use Disorders Identification Test (AUDIT). Mannheim, Zentrum für Umfragen, 2001.

44 Buckland PR, Hoogendoorn B, Guy CA, Coleman SL, Smith SK, Buxbaum JD, Haroutunian V, O'Donovan MC: A high proportion of polymorphisms in the promoters of brain expressed genes influences transcriptional activity. Biochim Biophys Acta 2004; 1690:238-249.

45 Cotton CH, Flint J, Campbell TG: Is there an association between NPY and neuroticism? Nature 2009;458:e6-e7.
46 Itokawa M, Arai M, Kato S, Ogata Y, Furukawa A, Haga S, Ujike H, Sora I, Ikeda K, Yoshikawa T: Association between a novel polymorphism in the promoter region of the neuropeptide $\mathrm{Y}$ gene and schizophrenia in humans. Neurosci Lett 2003;347:202-204.

47 Eaton K, Sallee FR, Sah R: Relevance of neuropeptide Y (NPY) in psychiatry. Curr Top Med Chem 2007;7:1645-1659.

48 Babor TF, de la Fuente JR, Saunders J, Grant M: AUDIT: The Alcohol Use Disorder Identification Test: Guidlines for Use in Primary Health Care. Geneva, WHO, 1992.

49 Bleich S, Havemann-Reinecke U, Kornhuber J: Der Fagerström-Test für Nikotinabhängigkeit (FTNA). Göttingen, Hogrefe-Verlag, 2002. 